\title{
Simulasi ETAP 12.6 untuk Studi Instalasi Listrik pada Kereta Api Kahuripan
}

\author{
FARIZ GHILYATS IRFAN, NASRUN HARIYANTO
}

Program Studi Teknik Elektro, Institut Teknologi Nasional Bandung, Indonesia Email: farizghilyatsirfan@gmail.com

Received 13 April 2021 | Revised 19 Mei 2021 | Accepted 29 Juni 2021

\begin{abstract}
ABSTRAK
Dalam sebuah satu rangkaian kereta biasanya terdiri dari penggerak utama lokomotif, kereta penumpang, kereta makan, dan kereta pembangkit. Dengan banyaknya fasilitas dan alat-alat kelistrikan dalam gerbong-gerbong tersebut dapat memberikan dampak penurunan terhadap kualitas daya listrik yang mengalir pada sistem distribusi aliran daya. Penelitian ini bertujuan untuk mengetahui kapasitas nilai circuit breaker, ukuran penampang kabel, tegangan jatuh, dan rugi-rugi daya, serta perbandingangannya dengan hasil simulasi pada software ETAP 12.6. Kapasitas circuit breaker dan ukuran penampang kabel yang diperhitungkan mendapatkan rating circuit breaker dengan arus berkisar dari 800 hingga 80 Ampere dan ukuran kabel yang digunakan sebesar $120 \mathrm{~mm}^{2}$. Hasil nilai drop voltage yang didapat dimulai dari 1,02 Volt hingga 5,08 Volt. Untuk nilai rugi-rugi daya yang didapat dimulai dari dari 0,01 kW hingga 0,11 kW.
\end{abstract}

Kata kunci: Aliran Beban, ETAP, Circuit Breaker, Drop Voltage, Rugi-rugi Daya.

\section{ABSTRACT}

A train usually consists of several carrieges: a prime mover locomotive, passenger carriage, dining carriage, and generator carriage. With that many facilities and installed electrical equipments the quality of the electric power flowing in the trains's power distribution system may be decresed. This study aims to determine the capacity of the circuit breaker, the cable's cross section size, the voltage drop, and power losses, as well as the comparison with the simulation results by using ETAP software. The circuit breaker capacity and cable's cross-sectional size are calculated. From the calculations, we obtain the rating value for the circuit breaker, which is ranging from 800 to 80 Ampere. As for the cable's corss sectional we obtain $120 \mathrm{~mm}^{2}$. With these values, the resulting voltage drop is from 1.02 Volts to 5.08 Volts. As for the resulting power loss, its value is ranging from $0.01 \mathrm{~kW}$ to $0.11 \mathrm{~kW}$.

Keywords: Load Flow, ETAP, Circuit Breaker, Voltage Drop, Power Loss. 


\section{PENDAHULUAN}

Dimulainya industri perkeratapian di Indonesia diawali pada jalur kereta api Solo-Yogyakarta oleh Gubernur Jendral Hindia Belanda. Setelah Indonesia meredeka pada 17 Agustus 1945 beberapa hari kemudian dilakukanlah pengambilalihan stasiun dan kantor pusat kereta api yang sebelumnya diduduki Jepang. Puncak pengambilalihan kantor pusat terjadi di Bandung pada tanggal 28 September 1945 yang menandakan awal berdirinya perkeretaapian di Indonesia (KAI, 2017).

Dalam sebuah satu rangkaian kereta biasanya terdiri dari penggerak utama lokomotif, kereta penumpang, kereta makan, kereta pembangkit dan kereta makan pembangkit (kereta makan yang disatukan dengan kereta pembangkit) (Hartono, 2012). Bahkan untuk beberapa kereta biasanya ditambah dengan kereta barang yang berfungsi untuk menempatkan barang-barang yang ukurannya khusus ditempatkan diarea yang lebih besar. Untuk kereta penumpang, makan, dan pembangkit memiliki fasilitas seperti lampu $T L$, pendingin $A C$, stopkontak, kamar mandi, TV, pengukur suhu ruangan, speaker, generator set, dan ruangan khusus seperti ruangan panel dan lain lain yang ditujukan untuk menunjang guna meningkatkan kenyamanan yang dirasakan petugas, pegawai, teknisi dan yang utama para penumpang.

Semakin banyak fasilitas pada kereta penumpang, dapat menimbulkan permasalahan kualitas daya listrik dan berdampak pada umur pakai peralatan. Kondisi ini harus dicegah dengan memiliki kualitas teknisi yang berkompeten di bidangnya dan sistem pemeliharaan atau perawatan kereta gerbong yang terjadwal dengan baik (Arfianto, Sukmadi, \& Winardi, 2013).

Analisis aliran daya adalah analisis yang bertujuan untuk mengetahui kondisi sistem tenaga listrik, apakah masih dalam kondisi aman atau sudah harus diganti. Sehingga dalam tema ini perlu persiapan sistem yang terukur untuk pemakaian jangka panjang (T \& Muksim, 2018). ETAP (Electrical Transient Analisis Program) adalah software yang dapat digunakan untuk untuk menghitung aliran daya pada sistem tenaga listrik (Nigara \& Primadiyono, 2015) (Kurniawan, Hani, \& Kristyana, 2019).

Pada penelitian ini software ETAP 12.6 berfungsi sebagai perangkat yang berguna untuk melakukan simulasi terhadap jenis-jenis bagian dari aliran daya dimana nantinya nilai tersebut akan menjadi acuan untuk dibandingkan dengan hasil perhitungan matematis sehingga mendapatkan kesimpulan kondisi kualitas aliran daya yang terjadi pada kereta api Kahuripan.

\section{METODOLOGI PENELITIAN}

\subsection{Diagram Alir}

Penulis mengerjakan penelitian ini dengan langkah-langkah pemecahan masalah yang ditunjukan pada diagram alir pada Gambar 1. 

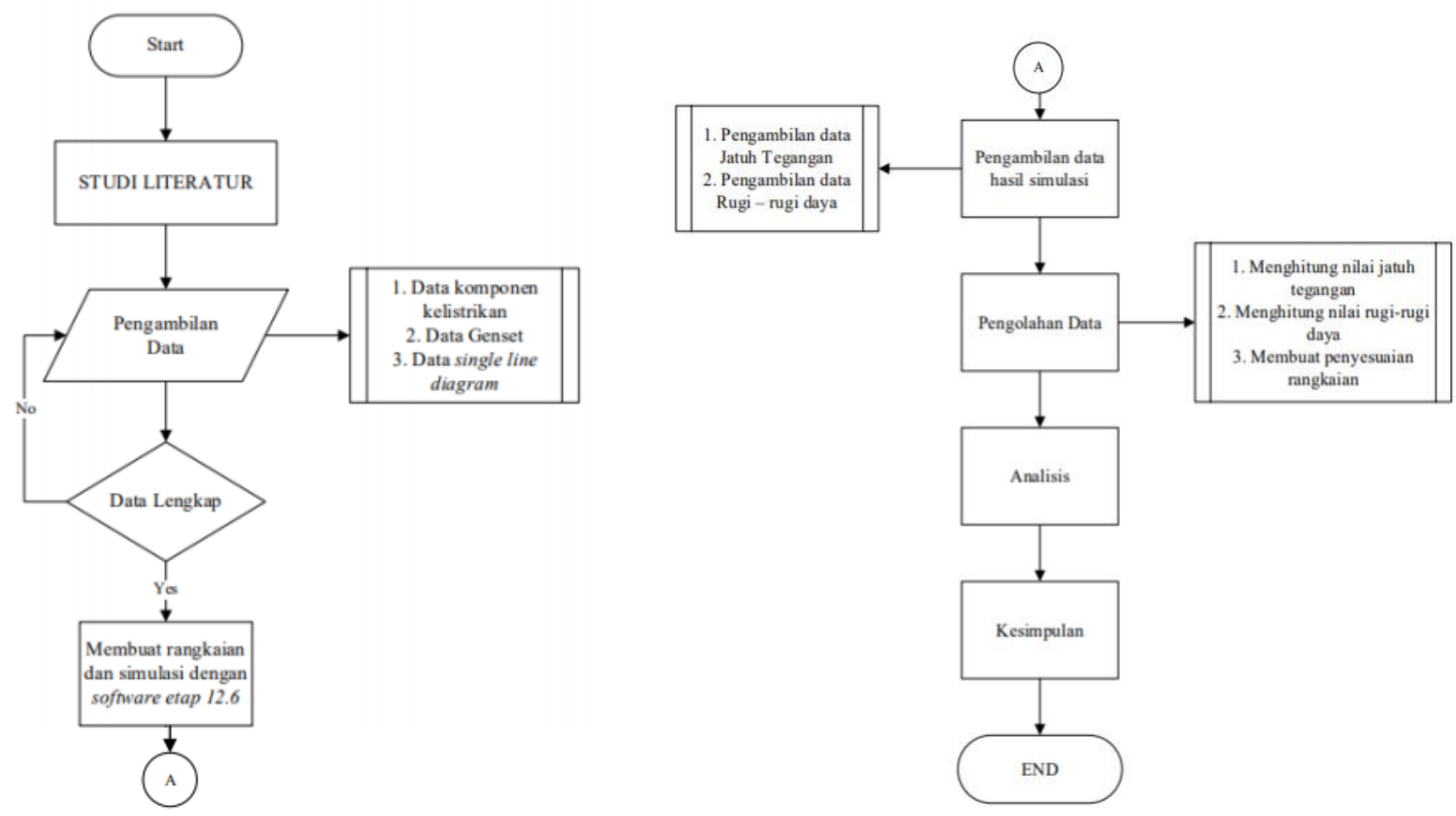

\section{Gambar 1. Diagram Alir Metodologi Penelitian}

\subsection{Perhitungan Kapasitas Circuit Breaker dan Ukuran Penampang Kabel}

Untuk melakukan perhitungan pada arus kabel digunakan persamaan sebagai berikut:

Keterangan:

$$
I_{n}=\frac{P}{V_{L L} \times \sqrt{3} \times \cos \emptyset}
$$

$I_{n} \quad=$ Arus nominal (Ampere)

$P \quad=$ Daya (Watt)

$V_{L L} \quad=$ Tegangan Fasa-fasa (Volt)

$\operatorname{Cos} \emptyset=0,8$

Keterangan:

$$
I_{\text {beban }}=I_{n} \times 125 \%
$$

$I_{n} \quad=$ Arus Nominal (Ampere)

$125 \%$ = Minimal arus pengenal beban penuh (PUIL, 2000).

\subsection{Perhitungan Tegangan Jatuh pada Saluran Penghantar}

Untuk melakukan perhitungan tegangan jatuh, pertama perlu diketahui nilai arus beban dengan persamaan sebagai berikut (Chapman, 1991):

Keterangan:

$$
I_{n}=\frac{P}{V_{L L} \times \sqrt{3} \times \cos \emptyset}
$$

$I_{n} \quad=$ Arus nominal (Ampere)

$P \quad=$ Daya (Watt)

$V_{L L} \quad=$ Tegangan Fasa-fasa (Volt)

$\operatorname{Cos} \emptyset=0,8$

\subsection{Perhitungan rugi-rugi daya}

Nilai panjang kabel (dalam meter) dari awal junction box ke junction box selanjutnya memerlukan data panjang distribusi. Disamping itu perlu diketahui luas penampang (A dalam 
$\mathrm{mm}^{2}$ ) serta jenis kabel yang dipasang untuk menentukan besar nilai massa jenis konduktor $(\rho)$. Saluran distribusi kereta ini menggunakan menggunakan tipe konduktor tembaga dengan nilai massa jenis konduktor $(\rho)=0,017241 \Omega \mathrm{mm}^{2} / \mathrm{m}$. Dari hasil sampel titik $\mathrm{G}$ ke titik 1 dengan panjang saluran $24 \mathrm{~m}$, maka dapat dihitung besarnya nilai resistansi pada kabel dengan Persamaan (4).

Keterangan:

$$
R=\frac{\rho 1}{A}
$$

$$
\begin{array}{ll}
\mathrm{R} & =\text { Resistansi(ohm) } \\
\rho & =\text { Masa jenis konduktor }(\rho) \\
\mathrm{I} & =\text { Panjang }(\mathrm{m}) \\
\mathrm{A} & =\text { Luas penampang }\left(\mathrm{m}^{2}\right)
\end{array}
$$

Rugi daya merupakan daya yang hilang akibat jatuh tegangan yang terletak di saluran distribusi. Nilai rugi daya dihasilkan menggunakan nilai resistansi ( $R$ dalam $\Omega$ /ohm) pada setiap saluran kabel yang sebelumnya telah dihitung, selanjutnya dikalikan dengan nilai arus (I dalam ampere) sesuai terhadap saluran kabel yang ada. Perhitungan rugi daya pada saluran kabel menggunakan Persamaan (5)

Keterangan:

$$
P=I^{2} \times R
$$

$$
\begin{array}{ll}
\mathrm{P} & =\text { Daya(Watt) } \\
\mathrm{I} & =\text { Arus(Ampere) } \\
\mathrm{R} & =\text { Resistansi }(\Omega)
\end{array}
$$

Untuk melakukan perhitungan rugi-rugi daya, maka didapatkan dengan dengan persamaan sebagai berikut:

Keterangan:

$$
P_{\text {Losses }}=i^{2} \times R
$$

$i=$ Arus pada beban (A)

$R=$ Resistansi

\subsection{Perhitungan Arus Short Circuit}

Untuk melakukan perhitungan arus short circuit, maka didapatkan dengan dengan persamaan sebagai berikut:

Keterangan:

$$
I_{S C}=\frac{V_{L L}}{\sqrt{3} \times Z_{\text {Genset }}+Z_{\text {total }}}
$$

$$
\begin{array}{ll}
V_{L L} & =\text { Tegangan fasa-fasa } \\
Z_{\text {genset }} & =\text { impedansi pada generator set } \\
Z_{\text {total }} & =\text { impedansi penjumlahan pada setiap saluran kabel }
\end{array}
$$

\subsection{Skenario Simulasi}

Simulasi menggunakan software ETAP ini dilakukan sebagai tolak ukur untuk membandingkan data riil di lapangan dengan data perhitungan (Tri, 2014). Penulis menggunakan data yang di ambil saat pengambilan data di Depo Kereta Bandung. Data beban tersebut dikelompokan menjadi 3 jenis pembebanan yaitu beban emergency, beban intermittent dan beban motor. Dalam pembuatan rangkaian di software ETAP, setiap gerbong berisikan masing-masing 3 jenis pembebanan yang sudah diberikan nilai jumlah total daya sesuai dengan jenisnya. Setelah rangkaian selesai diterapkan pada software, maka dilakukanlah simulasi Load Flow Analysis yang hasilnya akan menunjukan kondisi dari bus, circuit breaker, cable, drop voltage, dan losses apakah masuk kedalam kategori kondisi critical atau marginal. Sementara fitur branch losses summary report digunakan untuk menampilkan nilai tegangan jatuh dan rugi-rugi daya yang lebih detail akan nilai kenaikan 
atau penurunan tegangan maupun daya disetiap gerbong yang nantinya nilai tersebut akan dibandingkan dengan hasil perhitungan manual.

\section{DATA DAN ANALISIS}

\subsection{Data Beban Listrik pada Kereta}

Data yang dibutuhkan untuk simulasi diambil saat proses pengambilan data di Depo Kereta Bandung, data beban kelistrikan ditampilkan pada Tabel 1.

Tabel 1. Daftar Beban Listrik pada Kereta K1

\begin{tabular}{|c|c|c|c|c|c|c|}
\hline No & Vol & Sat & Uraian & Spesifikasi & Beban & Jumlah \\
\hline A & \multicolumn{4}{|c|}{ RUANG PENUMPANG } & & \\
\hline 1 & 20 & buah & $\begin{array}{l}\text { Lampu } \\
\text { saloon }\end{array}$ & $\begin{array}{l}\text { Lampu fluorescet } 36 \mathrm{~W}, 220 \mathrm{~V} \\
\text { AC, } 50 \mathrm{~Hz} *\end{array}$ & 80 & 1600 \\
\hline 2 & 50 & buah & $\begin{array}{l}\text { Lampu } \\
\text { baca }\end{array}$ & $\begin{array}{l}\text { Lampu pijar 10W, } 24 \mathrm{~V} \mathrm{AC,} \\
50 \mathrm{~Hz}\end{array}$ & 10 & 500 \\
\hline 3 & 2 & unit & $\begin{array}{c}\text { Lampu } \\
\text { emergency }\end{array}$ & $\begin{array}{l}\text { 2x10W /unit, terletak diujung } \\
\text { ruang saloon }\end{array}$ & 50 & 100 \\
\hline 4 & 2 & unit & $\begin{array}{l}\text { Lampu } \\
\text { informasi }\end{array}$ & $5 \mathrm{~W}, 220 \mathrm{~V} A C$ & 5 & 10 \\
\hline 5 & 2 & unit & $\begin{array}{c}\text { TV } \\
\text { LCD/LED }\end{array}$ & $\begin{array}{c}32 \text { inchi, } 220 \mathrm{~V} \mathrm{AC}, 80 \mathrm{~W}, 50 \\
\mathrm{~Hz}\end{array}$ & 80 & 160 \\
\hline 6 & 1 & set & $\begin{array}{l}\text { Stop } \\
\text { kontak }\end{array}$ & MCB $10 A^{*}$ & 3,085 & 3,085 \\
\hline B & \multicolumn{4}{|c|}{ KAMAR KECIL } & & \\
\hline 7 & 2 & buah & Lampu & $\begin{array}{c}2 \times 1 \text { Lampu fluorescet 20W, } \\
220 \mathrm{~V} \mathrm{AC}, 50 \mathrm{~Hz}\end{array}$ & 70 & 140 \\
\hline 8 & 2 & buah & $\begin{array}{l}\text { Exhaust } \\
\text { fan }\end{array}$ & $\begin{array}{c}2 \text { X } 1 \text { Kipas 70W, } 220 \text { V AC, } \\
\text { FV-40 AVU }\end{array}$ & 70 & 140 \\
\hline $\mathrm{C}$ & \multicolumn{4}{|c|}{ RUANG GANGWAY } & & \\
\hline 9 & 2 & buah & Lampu & $\begin{array}{c}2 \times 1 \text { Lampu fluorescet 20W, } \\
220 \mathrm{~V} \mathrm{AC}, 50 \mathrm{~Hz}\end{array}$ & 70 & 140 \\
\hline D & \multicolumn{4}{|c|}{ PERALATAN LAIN } & & \\
\hline 10 & 2 & unit & $\mathrm{AC}$ & 380 V AC, 50 Hz, 3 Phasa* & 12,461 & 24,922 \\
\hline 11 & 1 & set & Speaker & Dengan penguat & 500 & 500 \\
\hline \multicolumn{5}{|c|}{ TOTAL BEBAN } & & 31,297 \\
\hline
\end{tabular}

Dari daftar beban pada Tabel 1, akan dikelompokan ke dalam 3 jenis beban yang nantinya akan digunakan untuk merangkai rangkaian di software lalu dijalankannya simulasi Load Flow Analysis.

\subsection{Rangkaian dan Hasil Simulasi Load Flow Analysis}

Rangkaian Gerbong Kereta Kahuripan pada ETAP 12.6 setelah disimulasikan Load Flow Analysis ditunjukan pada Gambar 2. 


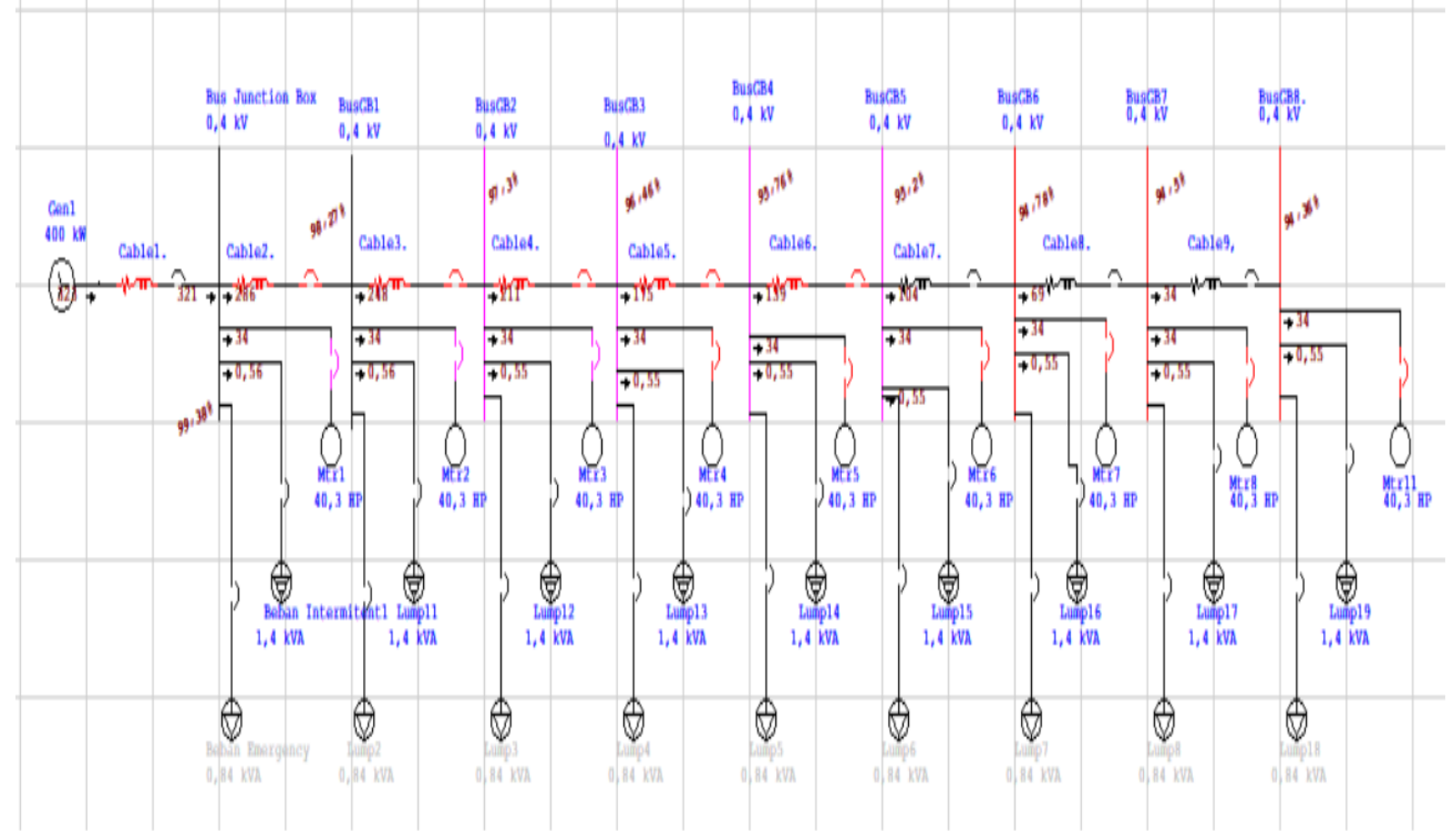

Gambar 2. Rangkaian Gerbong Kereta Kahuripan pada ETAP 12.6 Setelah disimulasikan Load Flow Analysis

Gambar 2 menampilkan kondisi rangkaian yang telah di-running simulasi Load Flow Analysis dimana nantinya akan keluar nilai-nilai kondisi tegangan saluran, arus saluran, kondisi kemampuan kabel dalam menerima arus yang mengalir (Wahyudianto, Sarwito, \& Kurniawan, 2016) (Pradnya, Arjana, \& Wijaya, 2017), dan kemampuan kondisi komponen apakah mampu atau tidak dalam menerima kondisi aliran daya yang tengah mengalir. Seletelah dilakukan simulasi maka dapat dilihat kondisi komponen saat fitur alert view diakftikan, kondisi tersebut ditunjukan pada Gambar 3.

\begin{tabular}{|c|c|c|c|c|c|c|}
\hline Device ID & Type & Condition & Rating/Limit & Operating & $\%$ Operating & Phase Type \\
\hline BusGBG6 & Bus & Under Vollage & $0,4 \mathrm{kV}$ & 0,379 & 94,8 & 3-Phase \\
\hline BusGB77 & Bus & Under Voltage & $0,4 \mathrm{kV}$ & 0,378 & 94,5 & 3.Phase \\
\hline BusGB8. & Bus & Under Voltage & $0.4 \mathrm{kV}$ & 0,377 & 94,4 & 3.Phase \\
\hline Cable1. & Cable & Overload & $433,366 \mathrm{Amp}$ & 579,688 & 133,8 & 3.Phase \\
\hline Cable2. & Cable & Overload & $216,683 \mathrm{Amp}$ & 517,331 & 238,8 & 3.Phase \\
\hline Cable3. & Cable & Overload & $216,683 \mathrm{Amp}$ & 454,275 & 209,6 & 3.Phase \\
\hline Cable4. & Cable & Overload & $216,683 \mathrm{Amp}$ & 390,591 & 180,3 & 3.Phase \\
\hline Cable5. & Cable & Overload & $216,683 \mathrm{Amp}$ & 326,358 & 150,6 & 3.Phase \\
\hline Cable6. & Cable & Overload & 216,683 Amp & 261,659 & 120,8 & 3.Phase \\
\hline CB1 & LVCB & Overload & $250 \mathrm{Amp}$ & 517,331 & 206,9 & 3.Phase \\
\hline CB16 & LVCB & Overload & 63Amp & 63,201 & 100,3 & 3.Phase \\
\hline CB18 & LV CB & Overload & 63Amp & 63,662 & 101,1 & 3.Phase \\
\hline $\mathrm{CB} 2$ & LVCB & Overload & $250 \mathrm{Amp}$ & 454,275 & 181,7 & 3.Phase \\
\hline $\mathrm{CB} 20$ & LVCB & Overload & 63Amp & 64,037 & 101,6 & 3.Phase \\
\hline CB22 & LVCB & Overload & 63Amp & 64,322 & 102,1 & 3.Phase \\
\hline $\mathrm{CB} 24$ & LV CB & Overload & 63Amp & 64,513 & 102,4 & 3.Phase \\
\hline $\mathrm{CB} 3$ & LVCB & Overload & $250 \mathrm{Amp}$ & 390,591 & 156,2 & 3-Phase \\
\hline $\mathrm{CB} 4$ & LVCB & Overload & $250 \mathrm{Amp}$ & 326,358 & 130,5 & 3-Phase \\
\hline CB40 & LVCB & Overload & 63Amp & 64,609 & 102,6 & 3.Phase \\
\hline CB5 & LVCB & Overload & $250 \mathrm{Amp}$ & 261,659 & 104,7 & 3.Phase \\
\hline \multicolumn{7}{|c|}{ Marginal } \\
\hline Device ID & Type & Condition & Rating/Limit & Operating & $\%$ Operating & Phase Type \\
\hline BusGB2 & Bus & Under Voltage & $0.4 \mathrm{kV}$ & 0,389 & 97,3 & 3.Phase \\
\hline BusGB33 & Bus & Under Vollage & $0,4 \mathrm{kV}$ & 0,386 & 96,5 & 3.Phase \\
\hline
\end{tabular}

Gambar 3. Kondisi Komponen Setelah Dilakukan Simulasi 
Gambar 3 menampilkan kondisi komponen pada rangkaian yaitu bus dan circuit breaker yang beberapa diantaranya berada dalam kondisi marginal yaitu kondisi dimana komponen yang beroperasi sudah mendekati batasnya beroperasinya. Untuk Kondisi tegangan jatuh dan juga rugi-rugi daya setelah rangkaian di-running simulasi Load Flow Analysis. Branch Losses Summary Report menampilkan asal dan tujuan daya serta tegangan yang mengalir pada rangkaian tersebut dapat dilihat saat fitur alert view diaktifkan ditunjukan pada Tabel 2.

Tabel 2. Kondisi Tegangan Jatuh dan Rugi-rugi Daya

\begin{tabular}{|c|c|c|c|c|c|c|c|c|c|}
\hline \multicolumn{10}{|c|}{ Branch Losses Summary Report } \\
\hline \multirow{2}{*}{$\begin{array}{c}\text { CKT / } \\
\text { Branch } \\
\text { ID }\end{array}$} & \multicolumn{2}{|c|}{$\begin{array}{l}\text { From-To Bus } \\
\text { Flow }\end{array}$} & \multicolumn{2}{|c|}{$\begin{array}{c}\text { To-From Bus } \\
\text { Flow }\end{array}$} & \multicolumn{2}{|c|}{ Losses } & \multicolumn{2}{|c|}{$\begin{array}{c}\text { \%Bus } \\
\text { Voltage }\end{array}$} & \multirow{2}{*}{$\begin{array}{l}\text { Vd \% } \\
\text { Drop } \\
\text { in V } \\
\text { mag }\end{array}$} \\
\hline & MW & Mvar & MW & Mvar & kW & kvar & From & To & \\
\hline Cable 1 & -0.321 & -0.238 & 0.323 & 0.239 & 2.3 & 1.1 & 99.4 & 100 & 0.62 \\
\hline Cable 2 & 0.286 & 0.212 & -0.283 & -0.21 & 3.6 & 1.8 & 99.4 & 98.3 & 1.11 \\
\hline Cable 3 & 0.248 & 0.184 & -0.246 & -0.183 & 2.8 & 1.4 & 8.3 & 97.3 & 0.97 \\
\hline Cable 4 & 0.211 & 0.157 & -0.209 & -0.156 & 2.1 & 1 & 7.3 & 96.5 & 0.84 \\
\hline Cable 5 & 0.175 & 0.13 & -0.173 & -0.13 & 1.4 & 0.7 & 96.5 & 95.8 & 0.7 \\
\hline Cable 6 & 0.139 & 0.104 & -0.138 & -0.103 & 0.9 & 0. & 95.8 & 95.2 & 0.56 \\
\hline Cable 7 & 0.104 & 0.078 & -0.103 & -0.077 & 0.5 & 0.3 & 95.2 & 94.8 & 0.42 \\
\hline Cable 8 & 0.06 & 0.052 & -0.069 & -0.052 & 0.2 & 0.1 & 94.8 & 94.5 & 0.28 \\
\hline Cable 9 & 0.034 & 0.026 & -0.034 & -0.026 & 0.1 & 0 & 94.4 & 94.4 & 0.14 \\
\hline & & & & & 13.9 & 7 & & & \\
\hline
\end{tabular}

Keterangan :

$V_{d} \quad:$ Voltage Drop / jatuh tegangan (volt)

$\% V_{d} \quad$ : Persentase jatuh tegangan (\%)

kW Losses : Rugi-rugi daya (kW)

Tabel 2 menampilkan kondisi tegangan jatuh dan rugi-rugi daya yang terjadi setelah rangkaian di-running simulasi Load Flow Analysis. Branch Losses Summary Report menampilkan asal dan tujuan daya serta tegangan yang mengalir pada rangkaian tersebut.

\subsection{Perhitungan Kapasitas Circuit Breaker dan Ukuran Penampang Kabel} Data hasil perhitungan kapasitas circuit breaker ditunjukkan pada Tabel 3.

Tabel 3. Data Hasil Perhitungan Kapasitas Circuit Breaker

\begin{tabular}{|c|c|c|c|c|c|c|c|c|}
\hline \multicolumn{9}{|c|}{ Perhitungan Kapasitas Circuit Breaker } \\
\hline \multicolumn{6}{|c|}{ Arus Beban } & \multirow{2}{*}{$\begin{array}{c}\text { In } x \\
1,25(A)\end{array}$} & \multirow{2}{*}{$\begin{array}{c}\text { Breaker } \\
\text { Type }\end{array}$} & \multirow{2}{*}{$\begin{array}{c}\text { Rating } \\
\text { Breaker } \\
\text { (A) }\end{array}$} \\
\hline Kabel & $\begin{array}{l}\text { Daya } \\
\text { (Kw) }\end{array}$ & $\begin{array}{l}\text { VLL } \\
\text { (V) }\end{array}$ & $\sqrt{3}$ & $\begin{array}{l}\text { Cos } \\
\text { Phi }\end{array}$ & $\begin{array}{l}\text { Arus } \\
\text { (A) }\end{array}$ & & & \\
\hline Kabel 1 & 319 & 400 & 1,73 & 0,8 & 575,55 & 719,43 & MCCB & 800 \\
\hline Kabel 2 & 280 & 400 & 1,73 & 0,8 & 505,18 & 631,48 & MCCB & 800 \\
\hline Kabel 3 & 244 & 400 & 1,73 & 0,8 & 440,23 & 550,29 & MCCB & 630 \\
\hline Kabel 4 & 209 & 400 & 1,73 & 0,8 & 377,08 & 471,35 & MCCB & 630 \\
\hline Kabel 5 & 174 & 400 & 1,73 & 0,8 & 313,93 & 392,42 & MCCB & 400 \\
\hline Kabel 6 & 139 & 400 & 1,73 & 0,8 & 250,79 & 313,48 & MCCB & 320 \\
\hline Kabel 7 & 104 & 400 & 1,73 & 0,8 & 187,64 & 234,55 & MCCB & 250 \\
\hline Kabel 8 & 34 & 400 & 1,73 & 0,8 & 61,34 & 76,68 & MCCB & 80 \\
\hline Kabel 9 & 34 & 400 & 1,73 & 0,8 & 61,34 & 76,68 & MCCB & 80 \\
\hline
\end{tabular}


Dalam distribusi ada kalanya gangguan arus hubung singkat yang disebabkan oleh banyak hal yang dampaknya terlihat pada penurunan performa distribusi (Agusutrisno, Prabowo, \& Wicaksono, 2020). Dari Tabel 3 data ditampilkan hasil perhitungan kapasitas circuit breaker dimana kabel 1 dan 2 sebesar 800 A, kabel 3 dan 4 sebesar 630 A, kabel 5 sebear 400 A, kabel 6 sebesar 320 A, kabel 7 sebesar 250 A, kabel 8 dan 9 sebesar 80 A. Ada dua jenis data sheet yang digunakan untuk menentukan ukuran panjang penambang diantaranya pada Tabel 4 adalah data sheet kabel NYAF jenis physical properties.

Tabel 4. Data Sheet Kabel NYAF dari Katalog Sutrado Jenis PHYSICAL PROPERTIES

\begin{tabular}{|c|c|c|c|c|c|c|}
\hline \multicolumn{7}{|c|}{ PHYSICAL PROPERTIES } \\
\hline Size & $\begin{array}{l}\text { No/Dia. } \\
\text { Of wire }\end{array}$ & $\begin{array}{c}\text { Insulation } \\
\text { Thickness }\end{array}$ & $\begin{array}{c}\text { Approx } \\
\text { Cable } \\
\text { Weight }\end{array}$ & $\begin{array}{c}\text { Standard } \\
\text { Length }\end{array}$ & Packing & $\begin{array}{c}\text { Min } \\
\text { Bending } \\
\text { Radius }\end{array}$ \\
\hline $\mathbf{m m}^{2}$ & $\mathrm{pcs} / \mathrm{mm}$ & $\mathbf{m m}$ & $\mathbf{k g} / \mathbf{k m}$ & $\mathbf{m}$ & - & \\
\hline 1.5 & $30 / 0.25$ & 0.7 & 30 & $50 / 100$ & coil & 30 \\
\hline 2.5 & $50 / 0.25$ & 0.8 & 3.7 & $50 / 100$ & coil & 30 \\
\hline 4 & $56 / 0.30$ & 0.8 & 4.6 & $50 / 100$ & coil & 40 \\
\hline 6 & $84 / 0.30$ & 0.8 & 5.4 & $50 / 100$ & coil & 50 \\
\hline 10 & $80 / 0.40$ & 1 & 7.3 & $50 / 100$ & coil & 70 \\
\hline 16 & $126 / 0.40$ & 1 & 8.4 & 1000 & drum & 80 \\
\hline 25 & $196 / 0.40$ & 1.1 & 10.2 & 1000 & drum & 100 \\
\hline 35 & $276 / 0.40$ & 1.2 & 11.8 & 1000 & drum & 110 \\
\hline 50 & $396 / 0.40$ & 1.4 & 14.1 & 500 & drum & 140 \\
\hline 70 & $360 / 0.40$ & 1.4 & 16.1 & 500 & drum & 160 \\
\hline 95 & $475 / 0.50$ & 1.6 & 18.2 & 500 & drum & 180 \\
\hline 120 & $608 / 0.50$ & 1.6 & 20 & 500 & drum & 200 \\
\hline 150 & $756 / 0.50$ & 1.8 & 22.2 & 500 & drum & 220 \\
\hline 185 & $925 / 0.50$ & 20 & 25 & 500 & drum & 250 \\
\hline 240 & $1.221 / 0.50$ & 22 & 27.9 & 500 & drum & 270 \\
\hline
\end{tabular}

Sedangkan Tabel 5 merupakan data sheet kabel NYAF jenis electrical properties.

Tabel 5. Data Sheet Kabel NYAF dari Katalog Sutrado Jenis ELECTRICAL PROPERTIES ELECTRICAL PROPERTIES

\begin{tabular}{|c|c|c|c|c|c|}
\hline \multirow{3}{*}{$\begin{array}{c}\text { Conductor } \\
\text { Resistance } \\
\text { at } 70 C \\
\mathrm{ohm} / \mathrm{km}\end{array}$} & \multirow{3}{*}{$\begin{array}{c}\begin{array}{c}\text { Insulation } \\
\text { Ressistance }\end{array} \\
\text { M.ohm.km }\end{array}$} & \multicolumn{2}{|c|}{$\begin{array}{c}\text { Current Carrying } \\
\text { Capacity at } 30\end{array}$} & \multirow{3}{*}{$\begin{array}{c}\begin{array}{c}\text { Short } \\
\text { circuit } \\
\text { Current } \\
\text { at } 1 \text { sec }\end{array} \\
\text { kA }\end{array}$} & \multirow{3}{*}{$\begin{array}{c}\text { AC Voltage } \\
\text { kV/5min. }\end{array}$} \\
\hline & & \multirow{2}{*}{$\frac{\text { in pipe }}{A}$} & \multirow{2}{*}{$\frac{\text { in air }}{A}$} & & \\
\hline & & & & & \\
\hline 13300 & 0.01 & 15 & 24 & 0.19 & 25 \\
\hline 7980 & 0.009 & 20 & 32 & 0.32 & 25 \\
\hline 4950 & 0.007 & 25 & 41 & 0.5 & 25 \\
\hline 3300 & 0.006 & 33 & 53 & 0.73 & 25 \\
\hline 1910 & 0.006 & 45 & 72 & 1.2 & 25 \\
\hline 1210 & 0.005 & 60 & 97 & 1.91 & 25 \\
\hline 780 & 0.004 & 82 & 128 & 2.96 & 25 \\
\hline 554 & 0.004 & 102 & 156 & 4.13 & 25 \\
\hline 386 & 0.004 & 131 & 195 & 5.87 & 25 \\
\hline 272 & 0.003 & 164 & 243 & 8.19 & 25 \\
\hline & & & & & \\
\hline
\end{tabular}




\begin{tabular}{|c|c|c|c|c|c|}
\hline \multicolumn{6}{|c|}{ ELETRICAL PROPERTIES } \\
\hline $\begin{array}{c}\text { Conductor } \\
\text { Resistance } \\
\text { at 70C }\end{array}$ & $\begin{array}{c}\text { Insulation } \\
\text { Ressistance }\end{array}$ & \multicolumn{2}{|c|}{$\begin{array}{c}\text { Current Carrying } \\
\text { Capacity at 30 }\end{array}$} & $\begin{array}{c}\text { Short } \\
\text { circuit } \\
\text { Current } \\
\text { at 1 sec }\end{array}$ & AC Voltage \\
\hline \multirow{2}{*}{ ohm/ km } & M.ohm.km & in Pipe & in Air & kA & kV/5min. \\
\cline { 3 - 6 } & 0.003 & 205 & 287 & 11.09 & 25 \\
\hline 206 & 0.003 & 233 & 342 & 13.98 & 25 \\
\hline 161 & 0.003 & - & 386 & 17.46 & 25 \\
\hline 129 & 0.003 & - & 441 & 21.5 & 25 \\
\hline 106 & 0.003 & - & 552 & 27.86 & 25 \\
\hline 80 & & & & & \\
\hline
\end{tabular}

Data sheet dari kabel NYAF dimana dari data tersebut kita bisa memilih ukuran kabel apa yang akan digunakan berdasarkan kuat hantar arus yang dimiliki dari hasil perhitungan arus nominal yang sudah dikalikan dengan nilai safety factor dari PUIL 2000. Data hasil perhitungan kapasitas breaker dan ukuran penampag kabel ditunjukan pada Tabel 6.

Tabel 6. Data Hasil Perhitungan Kapasitas Breaker dan Ukuran Penampang Kabel

\begin{tabular}{|c|c|c|c|c|c|c|c|c|c|c|c|}
\hline \multicolumn{7}{|c|}{ Arus Persaluran } \\
\hline Kabel & $\begin{array}{c}\text { Daya } \\
(\text { Kw) }\end{array}$ & $\begin{array}{c}\text { VLL } \\
\mathbf{( V )}\end{array}$ & $\sqrt{3}$ & $\begin{array}{c}\text { Cos } \\
\text { Phi }\end{array}$ & $\begin{array}{c}\text { Arus } \\
(\mathbf{A})\end{array}$ & $\begin{array}{c}\text { In X } \\
\mathbf{1 , 2 5} \\
(\mathbf{A})\end{array}$ & $\begin{array}{c}\text { A } \\
\left(\mathbf{m m}^{2} \mathbf{)}\right.\end{array}$ & $\begin{array}{c}\text { Tari- } \\
\text { kan }\end{array}$ & $\begin{array}{c}\text { Resis } \\
\text { tance } \\
\text { ohm/m }\end{array}$ & $\begin{array}{c}\text { Reak- } \\
\text { tansi }\end{array}$ & $\begin{array}{c}\text { Jen- } \\
\text { is }\end{array}$ \\
\hline $\begin{array}{c}\text { Kabel } \\
1\end{array}$ & 319 & 400 & 1,73 & 0,8 & 575,55 & 719,43 & 120 & 2 & 0,00016 & 0,073 & NYAF \\
\hline $\begin{array}{c}\text { Kabel } \\
\mathbf{2}\end{array}$ & 280 & 400 & 1,73 & 0,8 & 505,18 & 631,48 & 120 & 2 & 0,00016 & 0,073 & NYAF \\
\hline $\begin{array}{c}\text { Kabel } \\
3\end{array}$ & 244 & 400 & 1,73 & 0,8 & 440,23 & 550,29 & 120 & 2 & 0,00016 & 0,073 & NYAF \\
\hline $\begin{array}{c}\text { Kabel } \\
4\end{array}$ & 209 & 400 & 1,73 & 0,8 & 377,08 & 471,35 & 120 & 2 & 0,00016 & 0,073 & NYAF \\
\hline $\begin{array}{c}\text { Kabel } \\
5\end{array}$ & 174 & 400 & 1,73 & 0,8 & 313,93 & 392,42 & 120 & 2 & 0,00016 & 0,073 & NYAF \\
\hline $\begin{array}{c}\text { Kabel } \\
6\end{array}$ & 139 & 400 & 1,73 & 0,8 & 250,79 & 313,48 & 120 & 2 & 0,00016 & 0,073 & NYAF \\
\hline $\begin{array}{c}\text { Kabel } \\
7\end{array}$ & 104 & 400 & 1,73 & 0,8 & 187,64 & 234,55 & 120 & 2 & 0,00016 & 0,073 & NYAF \\
\hline $\begin{array}{c}\text { Kabel } \\
8\end{array}$ & 34 & 400 & 1,73 & 0,8 & 61,34 & 76,68 & 120 & 2 & 0,00016 & 0,073 & NYAF \\
\hline $\begin{array}{c}\text { Kabel } \\
9\end{array}$ & 34 & 400 & 1,73 & 0,8 & 61,34 & 76,68 & 120 & 2 & 0,00016 & 0,073 & NYAF \\
\hline
\end{tabular}

\subsection{Perhitungan Tegangan Jatuh pada Saluran Penghantar}

Data hasil perhitungan arus pada setiap beban ditunjukan pada Tabel 7. 
Tabel 7. Data Hasil Perhitungan Arus Beban

\begin{tabular}{|c|c|c|c|c|c|c|}
\hline \multicolumn{7}{|c|}{ Arus Beban } \\
\hline \multirow[b]{2}{*}{ Kabel } & \multirow[b]{2}{*}{ Arus } & \multicolumn{2}{|c|}{ Daya } & \multirow{2}{*}{$\begin{array}{l}\text { VLL } \\
\text { (V) }\end{array}$} & \multirow{2}{*}{$\begin{array}{l}\text { Cos } \\
\text { phi }\end{array}$} & \multirow{2}{*}{$\begin{array}{c}\text { Arus } \\
\text { Beban(A) }\end{array}$} \\
\hline & & $\begin{array}{l}\text { Kontinu } \\
\text { (kW) }\end{array}$ & $\begin{array}{c}\text { Intermitent } \\
(\mathbf{k W})\end{array}$ & & & \\
\hline Saluran 1 & i1 & 30 & 0,56 & 400 & 0,8 & 55,20 \\
\hline Saluran 2 & i2 & 30 & 0,56 & 400 & 0,8 & 55,20 \\
\hline Saluran 3 & i3 & 30 & 0,56 & 400 & 0,8 & 55,20 \\
\hline Saluran 4 & i4 & 30 & 0,56 & 400 & 0,8 & 55,20 \\
\hline Saluran 5 & i5 & 30 & 0,56 & 400 & 0,8 & 55,20 \\
\hline Saluran 6 & i6 & 30 & 0,56 & 400 & 0,8 & 55,20 \\
\hline Saluran 7 & i7 & 30 & 0,56 & 400 & 0,8 & 55,20 \\
\hline Saluran 8 & i8 & 30 & 0,56 & 400 & 0,8 & 55,20 \\
\hline Saluran 9 & ¡9 & 30 & 0,56 & 400 & 0,8 & 55,20 \\
\hline
\end{tabular}

Hasil perhitungan arus beban dimana karena semua beban nya sama maka nilai arus untuk arus bebannya pun sama dari kabel 1 hingga kabel 9 yaitu 55,20 A. Untuk melakukan perhitungan tegangan jatuh, maka didapatkan dengan dengan persamaan Deshpande, $\mathrm{M}$. (1984). Data hasil perhitungan tegangan jatuh ditunjukkan pada Tabel 8.

Tabel 8. Data Hasil Perhitungan Tegangan Jatuh

\begin{tabular}{|c|c|c|c|c|c|c|c|c|c|c|c|}
\hline \multicolumn{12}{|c|}{ Tegangan Jatuh } \\
\hline $\begin{array}{l}\text { Sec- } \\
\text { tion }\end{array}$ & $\begin{array}{l}\text { Arus } \\
\text { titik }\end{array}$ & $\begin{array}{c}\text { L } \\
\text { per } \\
\text { sect } \\
\text { ion } \\
\text { (m) }\end{array}$ & $\underset{(m)}{L}$ & $\sqrt{3}$ & $\begin{array}{c}\text { (Co } \\
\text { s } \\
\text { Phi) }\end{array}$ & $\begin{array}{l}\text { (Sin } \\
\text { Phi) }\end{array}$ & $\begin{array}{c}R \\
(\Omega / m)\end{array}$ & $\begin{array}{c}X \\
(\Omega / m)\end{array}$ & $\begin{array}{c}\Delta V \\
\text { (per- } \\
\text { secti } \\
\text { on) } \\
\text { (V) }\end{array}$ & $\begin{array}{c}\Delta V \\
\text { Tot } \\
\text { al } \\
\text { (V) }\end{array}$ & $\begin{array}{c}\Delta V \\
\text { Total } \\
(\%)\end{array}$ \\
\hline iG -i1 & 496,82 & 24 & 24 & 1,73 & 0,8 & 0,6 & 0,0016 & 0,00073 & 1,02 & 1,02 & 0,25 \\
\hline $\mathrm{i} 1-\mathrm{i} 2$ & 441,62 & 24 & 48 & 1,73 & 0,8 & 0,6 & 0,0016 & 0,00073 & 0,90 & 1,92 & 0,48 \\
\hline$i 2-i 3$ & 386,42 & 24 & 72 & 1,73 & 0,8 & 0,6 & 0,0016 & 0,00073 & 0,79 & 2,71 & 0,68 \\
\hline$i 3-i 4$ & 331,21 & 24 & 96 & 1,73 & 0,8 & 0,6 & 0,0016 & 0,00073 & 0,68 & 3,38 & 0,85 \\
\hline i4 - i5 & 276,01 & 24 & 120 & 1,73 & 0,8 & 0,6 & 0,0016 & 0,00073 & 0,56 & 3,95 & 0,99 \\
\hline i5 - i6 & 220,81 & 24 & 144 & 1,73 & 0,8 & 0,6 & 0,0016 & 0,00073 & 0,45 & 4,40 & 1,10 \\
\hline i6 - i7 & 165,61 & 24 & 168 & 1,73 & 0,8 & 0,6 & 0,0016 & 0,00073 & 0,34 & 4,74 & 1,18 \\
\hline i7 - i8 & 110,40 & 24 & 192 & 1,73 & 0,8 & 0,6 & 0,0016 & 0,00073 & 0,23 & 4,96 & 1,24 \\
\hline i8 - i9 & 55,20 & 24 & 216 & 1,73 & 0,8 & 0,6 & 0,0016 & 0,00073 & 0,11 & 5,08 & 1,27 \\
\hline
\end{tabular}

Pada dasarnya jatuh tegangan ialah selisih dari tegangan ujung pengirim dengan tegangan ujung penerima (Asy'ari, 2011) (Hontong, Tuegeh, \& Patras, 2015). Dari perhitungan tegangan jatuh, pada setiap bagian arus titik masing-masing yang dimana hasil dari nilai tegangan jatuh perbagian tersebut akan dijumlahkan secara berurutan sehingga nilai tegangan jatuh yang sesuai bisa didapatkan. Kurva perhitungan tegangan jatuh berdasarkan hasil perhitungan ditunjukan pada Gambar 4. 


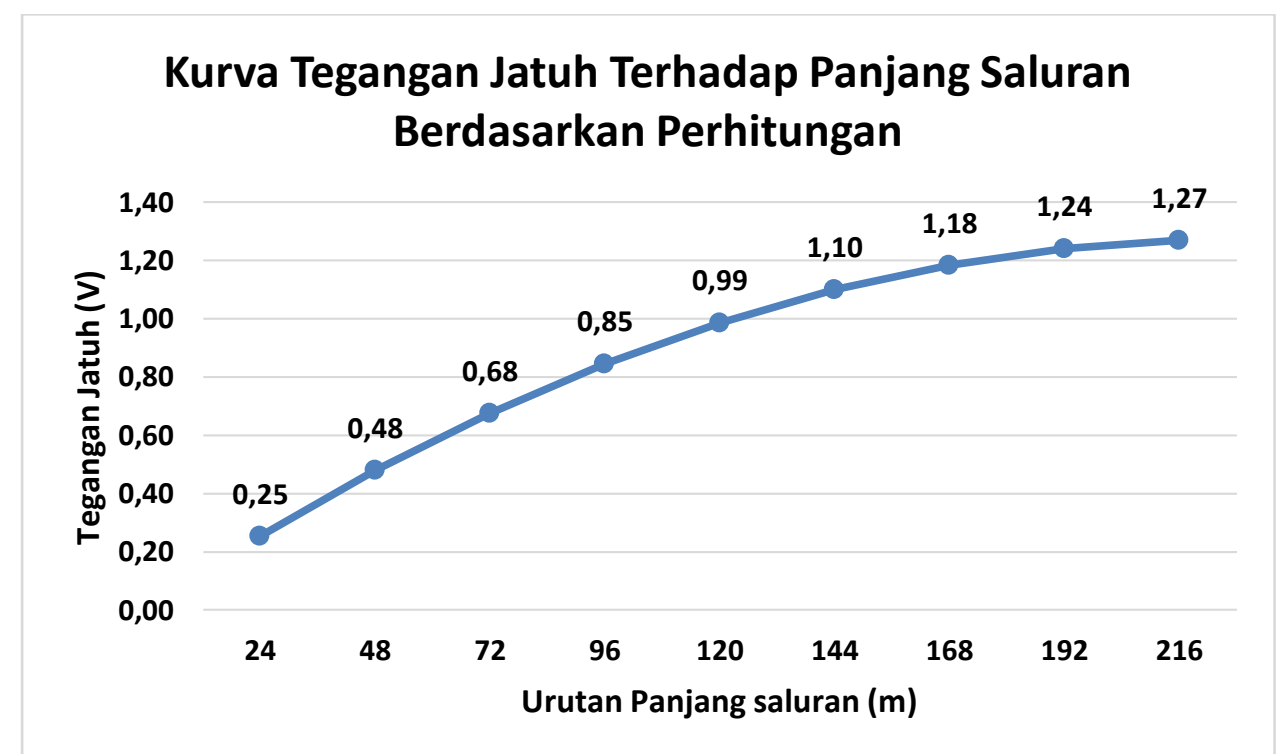

Gambar 4. Kurva Perhitungan Tegangan Jatuh Berdasarkan Hasil Perhitungan

Gambar 4 menampilkan kurva tegangan jatuh terhadap panjang saluran berdasarkan perhitungan dimana disetiap panjang yang berbeda nilai tegangan jatuh semakin lama semakin naik dari $0,25,0,48,0,68,085$, hingga terakhir adalah 1,27 Volt.

\subsection{Perhitungan Rugi-rugi Daya}

Berdasarkan Persamaan (4) dan (5) maka didapat nilai resistansi dan rugi-rugi daya yang ditunjukan pada Tabel 9.

Tabel 9. Data Hasil Perhitungan Rugi-Rugi Daya

\begin{tabular}{|c|c|c|c|c|c|c|}
\hline \multicolumn{7}{|c|}{ Perhitungan Rugi-rugi Daya } \\
\hline Kabel & $\begin{array}{c}\text { Amper } \\
\mathbf{e} \\
(\mathbf{A})\end{array}$ & $\begin{array}{c}\text { Panj } \\
\text { ang } \\
\mathbf{( m )}\end{array}$ & $\begin{array}{c}\text { Resista } \\
\mathbf{- n c e} \\
\mathbf{( \Omega / m )}\end{array}$ & $\begin{array}{c}\text { Resist- } \\
\text { ance }(\boldsymbol{\Omega})\end{array}$ & $\begin{array}{c}\text { Resist- } \\
\text { ance } \\
\text { Total }\end{array}$ & $\begin{array}{c}\text { Plosses } \\
\text { (kW) }\end{array}$ \\
\hline Kabel 1 & 55,20 & 24 & 0,00016 & 0,0038 & 0,0038 & 0,01 \\
\hline Kabel 2 & 55,20 & 48 & 0,00016 & 0,0077 & 0,0115 & 0,02 \\
\hline Kabel 3 & 55,20 & 72 & 0,00016 & 0,0115 & 0,0230 & 0,04 \\
\hline Kabel 4 & 55,20 & 96 & 0,00016 & 0,0154 & 0,0384 & 0,05 \\
\hline Kabel 5 & 55,20 & 120 & 0,00016 & 0,0192 & 0,0576 & 0,06 \\
\hline Kabel 6 & 55,20 & 144 & 0,00016 & 0,0230 & 0,0806 & 0,07 \\
\hline Kabel 7 & 55,20 & 168 & 0,00016 & 0,0269 & 0,1075 & 0,08 \\
\hline Kabel 8 & 55,20 & 192 & 0,00016 & 0,0307 & 0,1382 & 0,09 \\
\hline Kabel 9 & 55,20 & 216 & 0,00016 & 0,0346 & 0,1728 & 0,11 \\
\hline
\end{tabular}

Kurva Perhitungan nilai rugi-rugi daya pada saluran kabel ditunjukan pada Gambar 5 . 


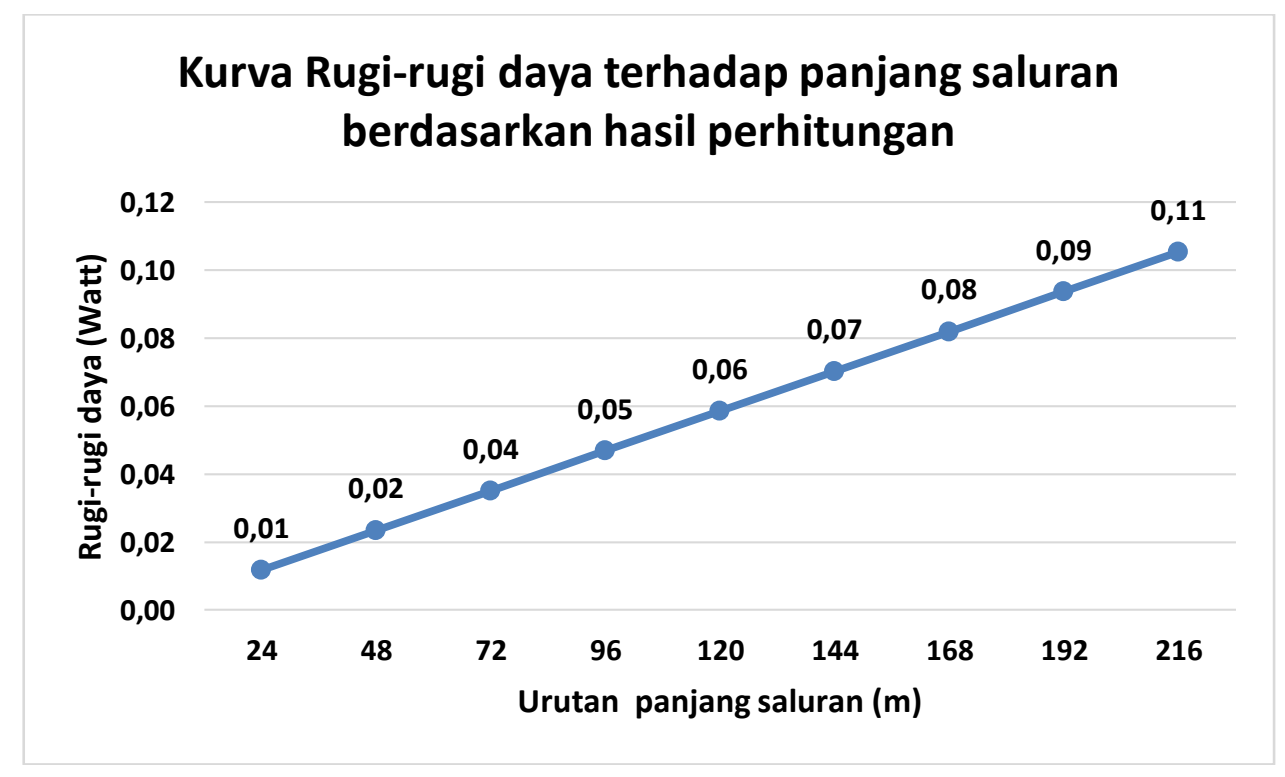

\section{Gambar 5. Kurva Rugi-Rugi Daya Berdasarkan Perhitungan}

Pada dasarnya rugi-rugi daya ialah daya yang hilang saat dalam proses pendistribusian yang mengakibatkan performa menurun (Hadisantoso, 2015). Pada Tabel 8 dan Gambar 5 ditunjukan hasil dan kurva perhitungan rugi-rugi daya terhadap saluran berdasarkan hasil perhitungan yang semakin lama semakin besar rugi-rugi dayanya diawali dari $0.01,0.02$, $0.04,0.05$ hingga 0.11 watt.

\subsection{Analisis}

Untuk kabel yang digunakan di simulasi dengan kabel yang digunakan dari riil dilapangan, hasilnya kabel memiliki kemampuan ketahanan yang sesuai. Ditunjukan dengan hasil dari simulasi load flow analysis dimana kabel tidak mengalami kondisi critical yang ditunjukan dengan warna merah pada komponen tersebut. Juga dengan circuit breaker memiliki kemampuan yang sama baik dalam etap maupun data dari lapangan. Hanya saja terlihat pada simulasi circuit breaker mengalami kondisi marginal dimana komponen beroperasi hampir mendekati batas kemampuannya. Jumlah konduktor pada kabel mempengaruhi naik turunnya kondisi tegangan jatuh di pengolahan data yang menggunakan software etap 12.6. Karena nilai arus sistem yang mengalir tidak boleh lebih besar dari pada nilai kuat hantar arus yang dimiliki kabel. Semakin jauh kabel, maka nilai arus kabel pun akan semakin kecil juga nilai dayanya pun semakin mengecil karena arus tersebut terbagi-bagi saat melewati kabel-kabel yang membawa beban masing-masingnya.

\section{KESIMPULAN}

Berdasarkan hasil simulasi juga perhitungan manual untuk sistem kelistrikan rangkaian kereta api Kahuripan dan analisis secara perbandingan untuk kedua metoda tersebut, didapatkan beberepa kesimpulan sebagai berikut:

1. Hasil nilai kapasitas circuit breaker yang didapat untuk: kabel 1 dan 2 sebesar $800 \mathrm{~A}$, kabel 3 dan 4 sebesar 630 A, kabel 5 sebesar 400A, kabel 6 sebesar 320 A, kabel 7 sebesar 250 A, kabel 8 dan 9 sebesar 80 A.

2. Ukuran penampang kabel yang didapat adalah $120 \mathrm{~mm}^{2}$ dengan jenis NYAF untuk 9 buah kabel yang digunakan. 
3. Dari hasil perhitungan nilai tegangan jatuh yang didapat adalah, $0.25 \%, 0.48 \%$, $0.68 \%, 0.85 \%, 0.99 \%, 1.10 \%, 1.18 \%, 1.24 \%, 1.27 \%$ sesuai dengan urutan kabel dari 1 hingga 9.

4. Dari hasil perhitungan rugi-rugi daya, didapat nilainya ialah $0.01,0.02,0.04,0.05$, $0.06,0.07,0.08,0.09,0.11$ dalam satuan kilowatt yang berurutan sesuai dengan kabelnya.

5. Dari data hasil pehitungan dengan simulasi terlihat perbandingan data jatuh tegangan dengan rugi-rugi daya memiliki sedikit perbedaan berkisar dari 0,01 hingga $0,02 \%$ yang masih berada dalam batas toleransi.

6. Pada penelitian ini dapat disimpulkan dimana hasil perbandingan nilai kapasitas circuit breaker, tegangan jatuh dan rugi-rugi daya memiliki hasil yang kemampuannya atau kapasitas nya sama baik dari perhitungan maupun simulasi.

\section{UCAPAN TERIMA KASIH}

Kepada PT. Kereta Api Indonesia khususnya Depo Kereta Bandung penulis mengucapkan banyak terima kasih karena telah meluangkan waktu dan kesempatan kepada penulis untuk berbagi ilmu dan pengalaman hingga penelitian ini dapat selesai.

\section{DAFTAR RUJUKAN}

Agusutrisno, Prabowo, \& Wicaksono. (2020). Studi Penempatan Circuit Breaker Outgoing (CBO) dan Perhitungan Relay pada Penyulang Puma Berdasarkan Pembacaan Arus Maksimal di Gardu Induk PLN New Bintaro. Jurnal Sains dan Teknologi, 61.

Arfianto, R. M., Sukmadi, T., \& Winardi, B. (2013). Analisis Konsumsi Daya Pada Gerbong Kereta Api Penumpang Kelas Eksekutif, Bisnis. dan Ekonomi (Di Depo Gerbong Kereta Api Indonesia). Transient, 362-369.

Asy'ari, H. (2011). Perbaikan Jatuh Tegangan dan Rekonfigurasi Beban pada Panel Utama Prambanan. Semantik, 1-5.

Chapman, S. J. (1991). "Electrics Machinery Fundamentals Second Edition". New York: McGraw-Hill.

Hadisantoso, F. S. (2015). Analisa Penurunan Tegangan (Voltage Drop) dan Rugi-rugi (Losses) Penyulang Menggunakan ETAP di Gardu Induk Bandung Selatan . Elektra, 42-53.

Hartono. (2012). Lokomotif \& Kereta Rel Diesel Indonesia 3rd edition. Depok: Ilalang Sakti Komunikasi.

Hontong, N. J., Tuegeh, M., \& Patras, L. S. (2015). Analisa Rugi - Rugi Daya pada Jaringan Distribusi di PT.PLN Palu. E-Journal Teknik Elektro dan Komputer, 67.

KAI, H. (2017, Februari 17). Sejarah Perkeretaapian Indonesia. Sejarah Perkeretaapian, p. 1. 
Kurniawan, R., Hani, S., \& Kristyana, S. (2019). Analisa Aliran Daya pada Sistem Tenaga Listrik di PT. Kirana Megatara Menggunakan Software Electric Transient and Analysis Program (ETAP) 12.6. Jurnal Elektrikal, 63.

Nigara, A. G., \& Primadiyono, Y. (2015). Analisis Aliran Daya Sistem Tenaga Listrik pada Bagian Texturizing di PT Asia Pasific Fibers Tbk Kendal menggunakan Software ETAP Power Station 4.0. Jurnal Teknik Elektro, 7-10.

Pradnya, M. A., Arjana, I. D., \& Wijaya, W. A. (2017). Stufi Analisis Dampak Pemasangan Over Load Shedding Terhadap Pembebanan pada Saluran Transmisi 150KV di Bali. Teknologi Elektro, 42.

PUIL, B. S. (2000). Perlengkapan Listrik. In B. S. Nasional, Persyaratan Umum Instalasi Listrik 2000 (p. 180). Bandung: Standar Nasional Indonesia.

T, A. B., \& Muksim, M. (2018). Simulasi dan Analisis Load Flow Sistem Interkoneksi Kalimantan Timur menggunakan Software ETAP 12.6. CIASTECH, 626-633.

Tri, F. (2014). Studi Pengaturan Tegangan Pada Sistem Distribusi 20 KV Menggunakan ETAP 7.0. Bandung: Universitas Pendidikan Indonesia.

Wahyudianto, M. F., Sarwito, S., \& Kurniawan, A. (2016). Analisa Tegangan Jatuh pada Sistem Distribusi Listrik di Kapal Penumpang dengan Menggunakan Metode Simulasi. Jurnal Teknik ITS, 344. 